\title{
SY2-4 【サルコイドーシスとその周辺疾患との関わり】
}

\section{肺の肉芽腫性疾患}

\author{
○宮崎泰成（みやざき やすなり）
}

東京医科歯科大学医学部呼吸器内科

サルコイドーシス (以下サ症) は、多臓器に原因不明の肉芽腫性病変を呈する疾患である。従って、そ の診断においては組織学的診断と鑑別診断が重要である。肺はサ症の臓器病変として頻度が高いこと、 健康診断システムが進んでいる日本では胸部レントゲン検査で発見される機会が多いこと、さらに気管 支鏡検査で組織学検査や気管支肺胞洗浄検査を行うことが可能であること、より肺病変にて診断される ことが多い。 肺の組織学的検査で肉芽腫性病変を認めた場合には表 1 にあげる疾患を除外する必要がある。 過敏性肺炎と慢性ベリリウム肺は、吸入性の抗原あるいは粉塵が肺内で反応して肉芽腫を形成するので 基本的に気道に沿つて病変が存在する。過敏性肺炎とサ症の合併が疑われる症例報告がある。抗酸菌症

(結核、非定型抗酸菌症) や真菌感染症（ヒストプラズマ症、ブラストミセス症、ニューモシスティス 肺炎）は、肺に肉芽腫を形成するので、培養検査や特殊染色が必要となる。血管炎関連疾患や免疫再構 築症候群では、臨床経過が類似することがあり、急性サルコイドーシスとの鑑別が問題となる。気管支 中心性肉芽腫症や肺ランゲルハンス細胞組織球症では、詳細な組織学的検討が必要となり、原発性免疫 不全症では特異な免疫反応に伴う肉芽腫との鑑別が難しいことがある。

両肺門リンパ節腫大 (bilateral hilar lymphadenopathy: BHL)を呈する様な典型的なサ症との鑑別は、 病歴、画像所見、検査所見などから容易に鑑別可能なことが多いが、肺病変を呈するサ症や急性のサ症 では、これらの疾患との鑑別が難しい。各疾患について実際の症例を提示しながら概説する。

\section{表 1 サ症と鑑別が必要な肺肉芽腫性疾患}

- 過敏性肺炎

・ じん肺（慢性ベリリウム肺）

- 感染症（抗酸菌、細菌、真菌、原虫、ウイルス）

- 薬剤性肺炎 (Drug-induced hypersensitivity)

- 異物型肉芽腫 (Foreign body granulomatosis)

- 血管炎関連：多発性血管炎性肉芽腫症（Wegener 肉芽腫症）、好酸球性多発血管炎性肉芽腫症 (Churg-Strauss 症候群)、肺リンパ腫様肉芽腫症（Pulmonary lymphomatoid granulomatosis）

- 気管支中心性肉芽腫症 (Bronchocentric granulomatosis)

- 肺ランゲルハンス細胞組織球症 (Pulmonary Langerhans cell histiocytosis)

- 原発性免疫不全症 (Primary immunodeficiencies)

- 免疫再構築症候群 (Immune reconstitution inflammatory syndrome: IRIS) 